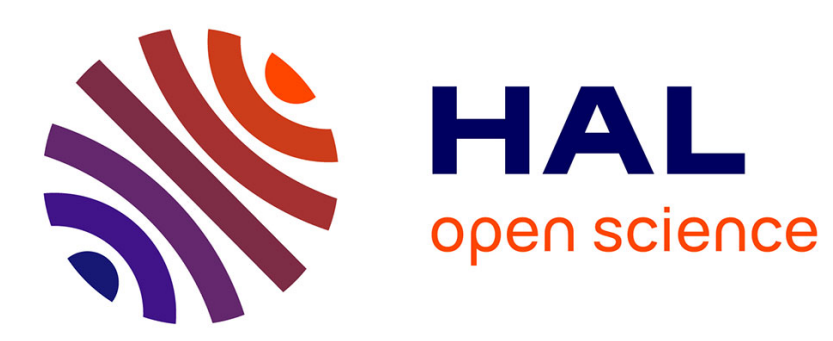

\title{
Eco-strategy: CSR strategy and Green IT updated model for ICT management
}

\author{
Rachid Hba, Abdellah El Manouar
}

\section{To cite this version:}

Rachid Hba, Abdellah El Manouar. Eco-strategy: CSR strategy and Green IT updated model for ICT management. International Journal of Scientific Research \& Engineering Technology (IJSET), 2017, 8 (1), pp.123-130. hal-01450262

\section{HAL Id: hal-01450262 \\ https://hal.science/hal-01450262}

Submitted on 7 Feb 2017

HAL is a multi-disciplinary open access archive for the deposit and dissemination of scientific research documents, whether they are published or not. The documents may come from teaching and research institutions in France or abroad, or from public or private research centers.
L'archive ouverte pluridisciplinaire HAL, est destinée au dépôt et à la diffusion de documents scientifiques de niveau recherche, publiés ou non, émanant des établissements d'enseignement et de recherche français ou étrangers, des laboratoires publics ou privés. 


\title{
Eco-strategy: CSR strategy and Green IT updated model for ICT management
}

\author{
Rachid Hba, Abdellah El Manouar
}

\begin{abstract}
Awareness of stakeholder interactions and sustainable development (SD) issues in the management of information and communication technologies (ICT), forces companies to adopt the concepts of Green IT and corporate social responsibility (CSR) to meet the challenges of agility and innovation, also to create differentiation in governance processes and strategic alignment of ICT. In this paper, we present the enhanced model of eco-strategy as a new generation model for ICT management, which will serve as a theoretical basis and aims to improve research in the field of responsible management of ICT. The updated eco-strategy model is composed of two dimensions: "ICT Green Governance" and "ICT Green Alignment". These dimensions were designed according to a Green IT and CSR approach to provide companies with tools for the development of coherent and sustainable managerial strategies capable of boosting overall performance and to explore new levers of transition towards renewed management modes in service the SD.
\end{abstract}

Index Terms-Governance, Strategic Alignment, Green IT, Responsible Management, Corporate Social Responsibility, Sustainable Development, ICT Management.

\section{INTRODUCTION}

$T^{t}$ HE reflection on the models of responsible management of Information and Communication Technologies (ICT) and their contribution or impact on sustainable development (SD) has aroused the interest of a large number of researchers in the field of information system. The analysis of management processes is at the origin of the research on ICT management strategies; this analysis of the processes was privileged by the researchers before taking an interest in the global management strategies which define which model or process to adopt.

Increasing attention to SD in the field of ICT encourages researchers to integrate the concept of sustainability into the design of management models to help companies cope with the environmental and social constraints of stakeholders and to gain competitive advantage. In recent years, several initiatives have been undertaken to analyze the impacts of ICT on the environment and society. However, the contexts are more complex and dynamic than many authors have thus specified the need to establish a systemic perspective for the integration of the concepts of SD in all the processes of management and decision-making in the ICT strategy [3], to strengthen the relationship between research and development and the exploitation of management models. To increase the implementation of this integration, some literature clarifies that aspects of sustainability should be included at all levels of the overall strategy [4]. Therefore the SD strategy in ICT management cannot be considered as an independent issue.

But given the increasing number of approaches to implementing existing SD recommendations and tools, the development of appropriate new models is becoming increasingly

- Rachid Hba is currently a PhD candidate at the ENSIAS Engineering School, Mohammed V University In Rabat, Morocco. Rachid got a national computer engineer diploma in 2005 from the ENSIAS (e-mail: rachid_hba@um5.ac.ma).

- Abdellah El Manouar, ENSIAS Engineering School, Mohammed V University In Rabat, Morocco. Abdellah holds a PhD in economics from Montreal University in 1991, Canada (e-mail:manouar@ensias.ma). complex [5]. The evolution of the challenges and opportunities for managing ICT, leads us to pilot a reflection on the strategic approach in a more global way and to highlight the fundamental questioning of the conventional management mode. In order to evolve existing ICT management approaches towards more sustainability and to present approaches based on the Triple Bottom Line (TBL) model that was represented in 1997 by John Elkington [1,2]. The aim is to integrate the concept of sustainability into the management strategy and to take account in a proportionate way of economic, social and ecological interests, thus guaranteeing a balance in order to reach all stakeholders in a sustainable and lasting way [1].

The use of responsible management practices that respects SD issues often refers to the Corporate Social Responsibility (CSR) approach and the Green IT concept [1]. In this view, we have introduced the initial model of the eco-strategy which proposes an original Framework composed of three dimensions [1]: the Green IT and CSR approach, governance and strategic alignment. As the dimension of Green IT and CSR is considered to be an orientation and homogeneous axis, given the cause-effect relationship between the adoption of Green IT practices and the CSR approach, this dimension has been declined on the other two axes which are the governance and alignment of ICTs in order to establish a systemic perspective to improve the integration of SD issues into the ICT management processes within the company. This perspective provides a comprehensive overview to address sustainability; the company must not only focus on the ICT management process but also on the strategic level impacting all stakeholders [3].

Based on the literature review, this paper assumes that the integration of SD concerns in the ICT management strategy can be improved by developing a new systematic approach between strategic, organizational and technical levels, thus creating awareness at all levels of the organization and across all business units and provide some pragmatic roadmaps for taking into account the environmental and social impact of the ICT management in the company. To help solve this problem, we will focus on our research project on the model of the eco- 
strategy cited in the previous paragraph. The aim is to propose an enhanced model to provide appropriate recommendations and new orientation for integrating sustainability into the ICT management field. We will introduce two new concepts, namely "ICT Green Alignment" and "ICT Green Governance" in the ICT management strategy; the first concept proposes a model of ICT alignment based on the CSR strategy and Green IT, while the second concept offers a new approach to governance that will be redesigned according to the Green IT and CSR vision:

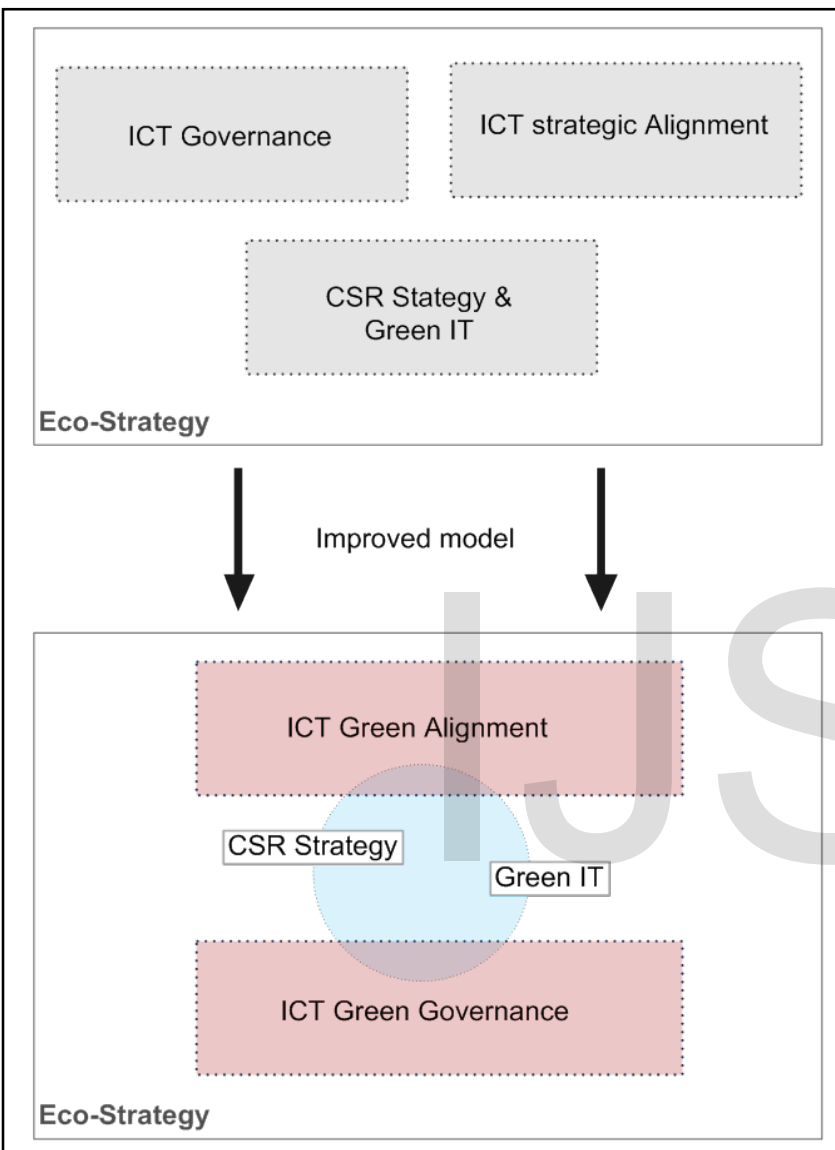

Fig. 1. Synthesis of the approach to improving the eco-strategy model.

The rest of this article is organized as follows. This paper first presents the state of research through a state of the art organized around an initial Framework of eco-strategy [1], in which we will recall the theoretical foundations of adoption of CSR and Green IT practices in the ICT governance and alignment process. Then we expose in a second place the enhanced model of the eco-strategy through the development of the different dimensions of the model. To conclude, some ideas will be proposed in order to elaborate a standard "ICT ecostrategist" allowing the certification of companies in the field of ICT management and also to present perspectives to evolve our model towards a referential of Green management

\section{TheORICAL ConTEXT AND Literature ReVIEW}

\subsection{From conventional to responsible ICT management}

Strategic management within companies is a relatively new concept that was institutionalized in 1980 after the work of Igor Ansoff and Anthony in 1965 [8, 9]. It represents all the managerial practices creating value in order to increase the profits and to have a better quality of life at work. The organization and mode of management have been influenced by the current socio-economic environment and the concept has been enriched by the contributions of organizational theory, industrial economics and technological innovation [12, 13]. Indeed, all the aspects of strategic management are in a state of mutation in relation to the past thanks to the ICT. Businesses are thus faced with a major development in their development [16], and with the complexity of following the managerial upheavals [13].

Technological innovation has contributed to the transformation of ICT managerial practices and has enabled companies to seek to rethink and develop new knowledge [10, 11]. This innovation has been propelled by the increase of interactions with all the stakeholders, enabling them to explore new management models thanks to the progress of the ICT. As a result, ICT with innovations are positioned at the core of enterprise managerial innovation [14]. The researchers are therefore interested in finding models of good practices to lead the innovation of management by relying on the ICT [13]. Other authors have also stressed the capacity of ICT to ultimately influence the managerial approach to organization, environment and stakeholders [6]. The objective is to seek, in a new analytical prism, to explore the levers of adaptation and evolution of the processes of conventional ICT management in a more systemic way and to meet the challenges of innovation.

With the penetration of ICT in companies, from the 1980s, the sphere of responsibility and the management dimensions of these ICT have expanded considerably. The challenge is to compensate or reduce the negative impacts of management on the environment and society and to lead to a transformation of the decision-making models, the social relations and the interactions induced by these ICT. This tendency is considered by researchers as a component of the company's environmental and societal identity [27], which has allowed us to question vertical models of management and hierarchical subordination [1]. At the heart of these new modes of managerial thinking, the adoption of practices respectful of the environment and in harmony with societal concerns becomes the preferred way for researchers to design a responsible management of ICT.

Responsible management, which is no more than the corporate social responsibility in our research, is undoubtedly a practice in step with the new demands of SD that can lead to change and continuous improvement, with a view to sustainability and full respect for environmental balances [20]. In this new field of research, ICT qualified as Green IT [1] seems to play an essential role as an engine and catalyst for the new management and decision-making strategy [24]. In this context, companies increasingly tend to adopt practices known as Green IT [21] to satisfy the objectives of all stakeholders [1]. However, in order to make the management strategy viable, 
researchers are challenged to develop new management models that, through ICT, would enable companies to achieve competitive advantages in terms of increased profits and minimized costs, and through the intelligent and ecological use of resources [22]. The models to be proposed must thus be able to integrate the variety of impacts of ICT, not only economic but also environmental and social [23], with a view to innovation and the creation of differentiation.

Consequently, in our research work, we envisage contributing to the reflection on the new ICT management systems, which we will refer to as new generation managerial systems. To answer the lack of consideration of SD principles and criteria in the design of management models, we proposed the concept of eco-strategy [1]. This initial model is built around the CSR approach and Green IT, which explains the strength of our proposal, is that it integrates transversely these two concepts in the process of governance and strategic alignment of ICT.

\subsection{The initial model of the Eco-strategy based on Green IT and RSE}

In order to integrate the concept of SD into ICT management strategy and IT policies and processes, we have introduced the initial model of eco-strategy [1] which is based on the concept of Green IT and the CSR approach. Our contribution aims to participate in the reflection on the new methods of ICT management. The reflection was guided by a new societal and environmental orientation, as well as broad avenues of improvement of the practices and procedures of governance and alignment. The two main ICT management sectors introduced by the eco-strategy model are:

- Greater accountability to all stakeholders

- Continuous improvement and sustainability of governance practices and strategic alignment of ICT based on an integrated Green IT and CSR strategy

The objective of the initial model has been to design a managerial Framework that takes into account the concerns of SD in the processes of alignment and governance of ICT:

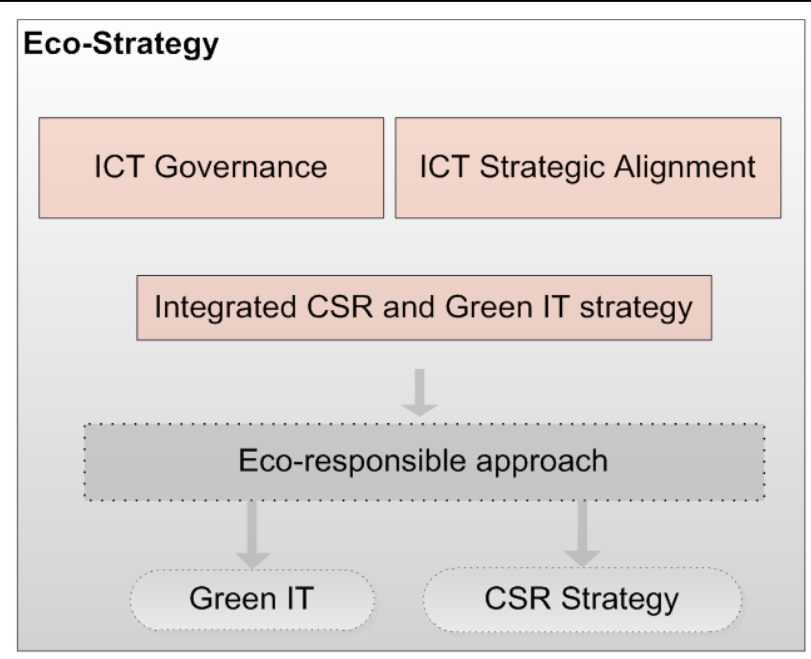

Fig. 2. Initial model of the eco-strategy.
We described in this Framework the internal and external visions of ICT management, which offers a perspective based on the practices of Green IT and the CSR strategy in the processes of governance and strategic alignment of ICT:

\begin{tabular}{|l|l|}
\hline \multicolumn{2}{|c|}{ TABLE 1 } \\
\multicolumn{1}{|c|}{$\begin{array}{l}\text { Internal Vision } \\
\text { Management Effec- } \\
\text { tiveness }\end{array}$} & $\begin{array}{l}\text { Single customer value } \\
\text { creation }\end{array}$ \\
\hline Minimization of costs & $\begin{array}{l}\text { Sustainable develop- } \\
\text { ment issues }\end{array}$ \\
\hline $\begin{array}{l}\text { Improved coordina- } \\
\text { tion of activities }\end{array}$ & $\begin{array}{l}\text { Competitiveness and } \\
\text { leadership }\end{array}$ \\
\hline $\begin{array}{l}\text { Transformation and } \\
\text { innovation }\end{array}$ & $\begin{array}{l}\text { Performance and } \\
\text { compliance }\end{array}$ \\
\hline Strategic Adjustment & Economic Intelligence \\
\hline Process optimization & Stakeholders \\
\hline
\end{tabular}

This initial model requires taking into account the factors of Green IT and CSR to strengthen conventional governance methods, in order to integrate the concept of sustainability into ICT governance instruments and mechanisms [1]. The recommended approach makes it possible to identify the demands of all the stakeholders with a goal of risk control, performance and compliance in an eco-responsible approach and sustainable use of resources. We talk about a certain eco-governance based on economic, societal and environmental intelligence.

For the strategic alignment dimension of ICT, the ecostrategy model offers an approach to improving the adjustment process from an internal point of view, by synchronizing the actions of CSR and Green IT With the strategic orientations of ICT at company level. We also aim to give priority to technical and managerial innovation and transformation. From an external point of view, the model focuses on branding and intellectual property. The transformation brought about by the CSR and Green IT approach creates differentiation and aims to improve and develop competitiveness and leadership [1].

\subsection{Findings and Motivation}

As demonstrated by the literature review, Green IT and CSR practices may, indeed, have the ability to help the company gain competitive advantage and contribute to the achievement of SD goals. The implementation of coherent and eco-responsible ICT management initiatives supports the overall management strategy and facilitates the creation of competitive differentiation. The initial eco-strategy model provides an effective management Framework for integrating SD concepts into the ICT governance and alignment strategy, however, the interrelatedness of the management strategy, the objectives of the CSR and Green IT is a complex challenge.

Our model needs a solid justification for driving sustainability initiatives to establish on-line priorities with the company's core ICT business. The initial model does not provide the necessary strategies and practices at all levels that can address 
the issues raised by the SD. In addition, the model offers two distinct visions for the integration of the CSR and Green IT approach [1]. This is why a more enhanced and cross-sectoral Framework is strongly needed in order to respond to both governance decision-making and strategic alignment of ICT, taking into account in an integrated approach the requirements of CSR and Green IT. The objective is to evolve from a three-dimensional model with two visions towards a new two-dimensional management model in an eco-strategic approach to Green IT and CSR. The dimensions of the model will be integrated into the theoretical Framework of the responsible management strategy to facilitate the link between the governance and alignment practices and the managerial context of the company's ICT in relation to all the stakeholders.

\section{Theorical Context AND Literature ReVIEW}

To answer the problem, we remember that the latter refers to the observation of a lack of conceptualization of systems based on Green IT and CSR for the ICT management. The analysis of the literature shows the weakness of research investigations in this field. We address this problem by proposing a theoretical model of new generation management, consisting of a conceptual model of governance and strategic alignment of ICT based on the concepts of Green IT, CSR and stakeholder theory [1]. The fundamental objective of this model is to contribute to the fields of research in the domains of strategic management of ICT by giving new insights about the relevance of the concept of Green IT and CSR to increase the creation of value [38], increase competitiveness and leadership and support the environmental and societal purposes of the company to create the differentiation.

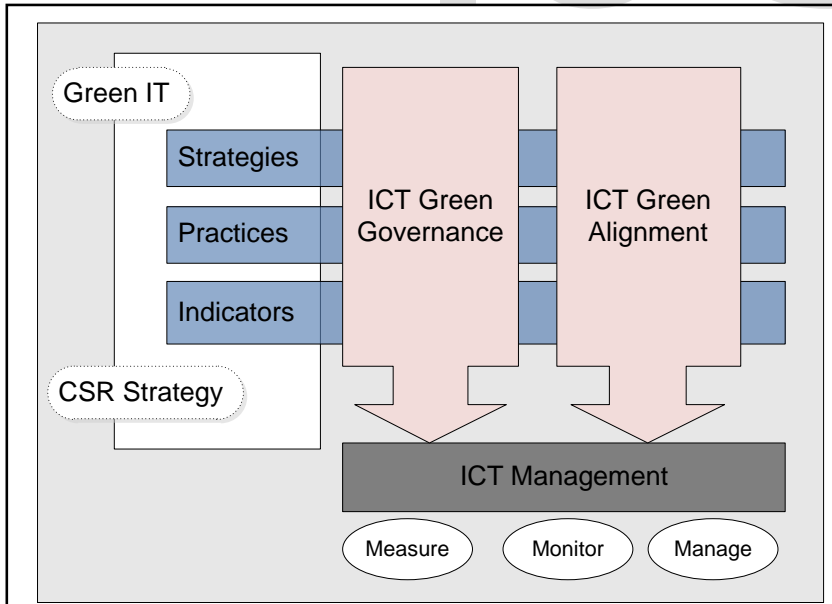

Fig. 3. Enhanced model of the eco-strategy.

The remainder of this paper is structured as follows: in the first chapter, we define the integrated approach of Green IT and CSR that will be adopted in our research. This approach is crucial in our conception of the strategic management of ICT; we will analyze the strategic relevance of the notion of sustainability which facilitates consideration of the strategic aspects of Green IT and CSR. In the second chapter of the article, we present the notion of "ICT Green Governance" as the first di- mension of the updated model of eco-strategy. In this section, we detail the new ICT governance dimension that is rethought according to the approach Green IT and CSR by proposing SD best practices and strategies. The third chapter will discuss the second dimension of our model and introduce a new concept that is "ICT Green Alignment" through the development of a conceptual Framework for the strategic alignment of ICTs using the Green IT and CSR approach.

\subsection{The integrated approach of Green IT and CSR in ICT management}

The key motivation for our contribution is to promote all Green IT and CSR approaches in an integrated manner in the ICT governance and alignment processes [1]. This approach is represented in our model as being a transverse axis to the set of the stakeholders, this axis is made up of three main components of the Green IT and CSR: Strategies, Practices, Indicators, these components are modeled according to the different contexts that are defined by the stakeholders; We talk about the internal, external and technological context.

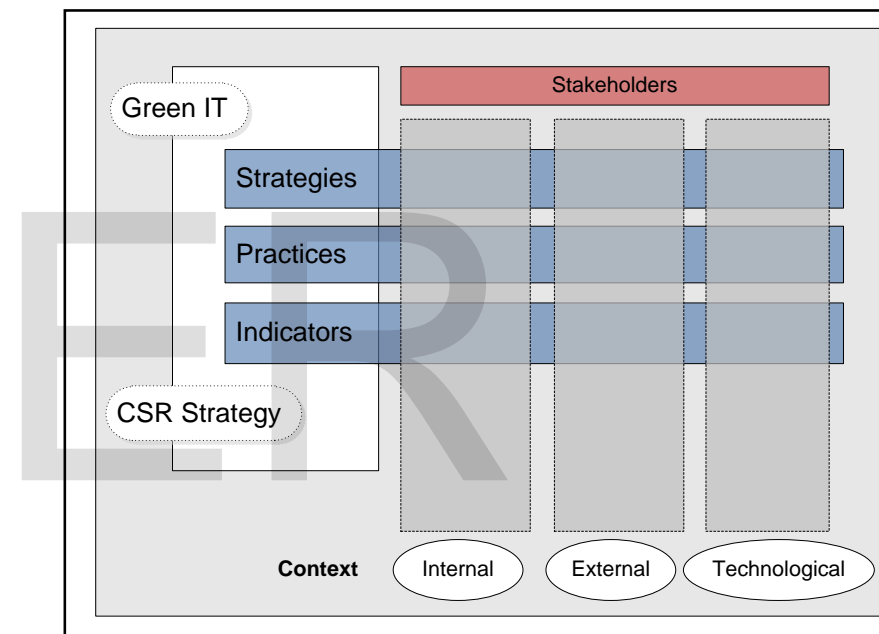

Fig. 4. Green IT and CSR integrated approach.

These components will be further detailed according to the context and refined to provide the appropriate elements, which will allow us to design the two dimensions (ICT Green Governance and ICT Green Alignment, see figure 3), the objective is to align the ICT governance and alignment processes with the integrated Green IT and CSR strategy.

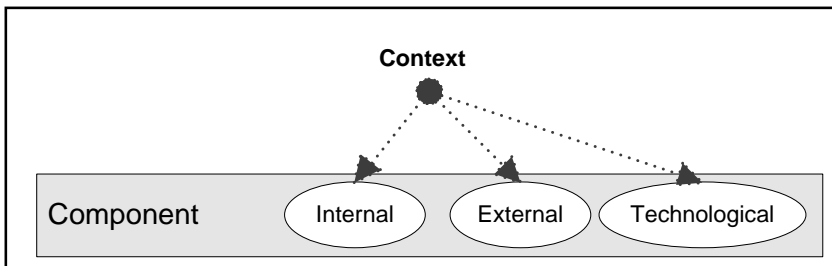

Fig. 5. Dimensional view of the components of the integrated Green IT and CSR approach.

\section{Strategies:}

The "Strategies" component is defined in our research as a 
concept that designates policies to integrate societal, environmental and economic concerns associated with the concept of Green IT in ICT governance and alignment processes:

- Societal strategy: defines the policy to lead the impacts that ICT management can have on the social systems within which it operates.

- Environmental strategy: is interested in implementing an action plan to reduce the ecological footprint of ICT management and improve the standard of living.

- Economic strategy: allows controlling the impacts that ICT management can have on economic systems at the local, national and global levels.

\section{Practices:}

The "Practices" component refers to techniques and behaviors that managers and organizations can adopt and help directly in the greening of the ICT management function:

- The societal component:

- Strengthening human capital

- Promoting diversity

- Encouragement of continuous and high-quality social dialogue

- Management of promotions

- Guarantee of freedom of association and collective bargaining

- Access to education

- Health and safety at work, well-being in the company

- Skills development and training

- Equality between men and women

- Conduct and compliance with high standards of ethics

- The environmental component:

- Controlling environmental risks, selecting and improving the quality of projects

- Environmental performance

- Measuring the carbon footprint

- Resource-saving policy

- Energy saving policy

- Waste sorting, recycling and recovery

- Eco-design

- Optimization of the logistics chain

- The Economic Component:

- Good risk and performance management

- Responsible purchasing and procurement policy

- The supply of responsible products and services

- Business ethics and the fight against corruption

- The strategic contribution

- Operational Excellence

\section{Indicators:}

The objective of setting up indicators is to enable the optimization of our eco-strategy plan for the responsible management of ICT, through an initial evaluation and a follow-up of their evolution within the Framework of an approach to progress and continuous improvement [30]. These indicators are defined and applied to the two pillars of our model (ICT Green Governance and ICT Green Alignment). Each indicator is clearly identified according to appropriate measures to allow us to conduct an eco-strategic process of management on three phases that we call "the Three Ms"

- Measure: implementation of measures on indicators in all aspects (strategy and practice) of ICT governance and alignment processes

- Monitor: monitoring over time to determine the evolution of indicators

- Manage: interpretation of measurement and monitoring results for the continuous improvement of management processes

\section{2 "ICT Green Governance" Dimension}

The enhanced eco-strategy model we propose through its "ICT Green Governance" dimension addresses the sustainability challenges already described, ensuring SD-oriented integration into the ICT governance process [26]. This dimension is designed on four strategic axes in order to put in place good ICT governance and also to create differentiation through the creation of value for all the stakeholders. The objective of sustainable governance of ICT is, through the guidelines and specifications of Green IT and CSR, to ensure responsible management within the organization by identifying and assessing the risks associated with sustainability, good resource management and the implementation of effective sustainability monitoring [22].

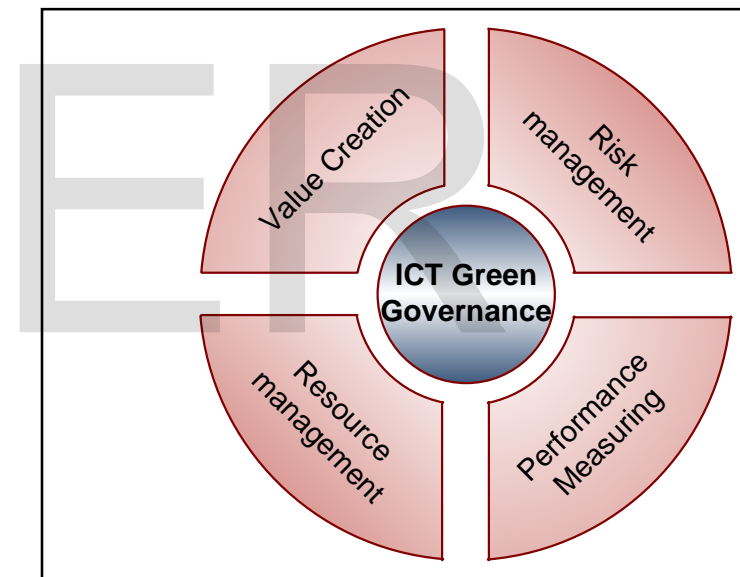

Fig. 6. "ICT Green Governance" Dimension.

\section{Resource Management}

Consists of optimizing investment in ICT resources and managing them, as well as optimizing knowledge about infrastructures, applications, information and people.

\section{$\underline{\text { Risk management }}$}

We require IT managers to be aware of and have a clear view of the risk appetite of the company, as well as to have a good knowledge of the compliance requirements and transparency about the significant risks incurred by the company [30]. The aim is to have a better allocation of responsibilities in risk management for different stakeholders.

\section{Value Creation}

The main objective of this axis is to implement the sustainability proposal as an added value throughout the ICT governance process and ensure that the expected benefits are achieved strategically. The creation of value in our model aims 
to prove the intrinsic value of ICT through the practices of Green IT and CSR [38], taking care to optimize costs, manage risks and ensure the sustainability of resources [22].

\section{Measuring performance}

We propose in our model a new way to monitor the implementation of the ICT governance process, we are interested in environmental, societal and economic performance through a dashboard designed on a set of indicators of Green IT and CSR.

\section{3 "ICT Green Alignment" Dimension}

In the remainder of this paper we will seek to fill the gap in the literature on the strategic alignment of ICT in the CSR and Green IT approach. Then we provide a new conceptual alignment Framework that will be the second dimension of our ecostrategy model, which is complementary to the ICT Green Governance dimension and can be used to describe strategic alignment strategies revised according to a SD strategy based on Green IT and CSR.

The subject of strategic alignment of ICT has been the central concern of managers for many years [41]. The challenge is to exploit the potential of ICT to achieve the objectives expected by companies [42]. The Strategic Alignment Model (MAS), developed in 1993 by Professor Venkatraman at the MIT Sloan School of Management in Boston, proposes a Framework for ICT alignment based on four axes: technological strategy, business strategy, IT resources and organization, the objective of this model is to achieve competitive advantage. The MAS model is also concerned with the impact of ICT on the organizational interrelationships between strategic and technological planning. From the last ten years, SD initiatives focused on the Green IT and the CSR strategy, represent a new and very complex challenge in the process of aligning these ICT with the commercial strategy. Alignment in the context of the CSR and Green IT strategies is seen as a driving force in transforming the whole economic, societal and environmental logic of the company.

The strategy for aligning ICT within the integrated Green IT and CSR approach already defined in Chapter 3.1 is essential in order to increase competitiveness and contribute to the achievement of sustainability objectives. This requires a strategic plan that will guide the entire alignment strategy in full respect of SD concerns [13]. According to the work carried out in 2006 by Wang and Ghose [44], they propose a conceptual model that offers a set of tools that promote the synergy between alignment strategy and Green IT. The same authors pointed out in 2011 that the proposed model, taking into account the allocation of resources [45] and offering adequate alignment measures to achieve business and sustainability objectives, are a crucial both managerial and academic [46]. This will help us in our research approach to design a new dimension of ICT alignment in our overall eco-strategy model.

For this purpose, we will adopt a holistic approach based on the "Balanced Scorecard" concept, which was developed in 1992 by Kaplan and Norton [47] as part of a research project to study measurement of performance in companies. The concept focused on four perspectives: finance, customer, operational processes, learning and growth. We propose to modify this concept in order to align with the three dimensions of the integrated Green IT and CSR strategy that we have put in place. This approach is more effective in improving the alignment process of ICT through Green IT and CSR practices by playing a central role in creating value for all stakeholders. We introduce the "ICT Green Alignment" dimension, which is designed on the following three axes: business strategy, ICT strategy, societal and environmental strategy, these three axes are aligned according to the approach of Green IT and CSR as shown in figure below:

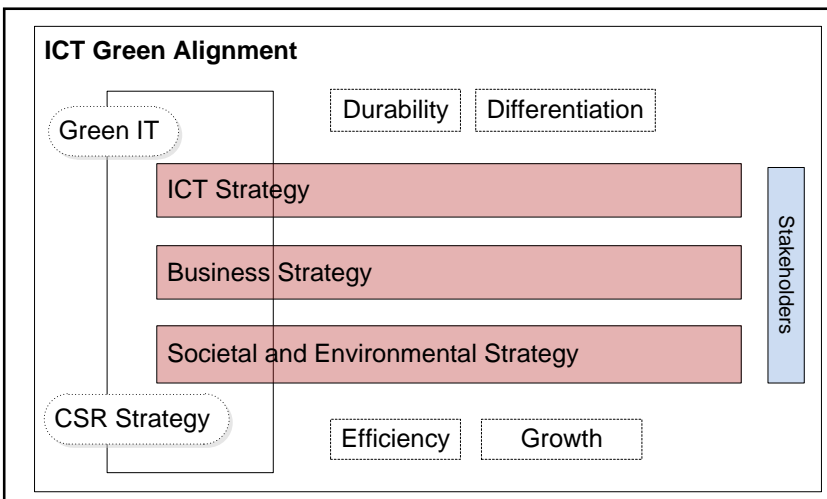

Fig. 7. "ICT Green Alignment” Dimension.

The ICT strategy is aligned with the Green IT strategy, what allows to reach the objectives of sustainability and technological efficiency in terms of energy saving and value creation. This strategy promotes the creation and exploration of new SD business opportunities and improves societal and environmental strategy through technological and organizational practices based on innovation and differentiation. By promoting differentiation in ICT managerial practices, this has a direct impact on the economic process through the creation of the single customer value [1] and also introduces a change in current business practices.

\section{Conclusions And Perspectives}

In this paper, we presented the enhanced model of ecostrategy, which we have described as a new generation management model, has been redesigned according to an integrated approach of Green IT and CSR. The model presented constitutes a Framework of managerial strategy for the governance and strategic alignment of ICT in an SD approach. The major contribution in this paper is the transformation of the initial three-dimensional model to a new two-dimensional enhanced and transverse model "ICT Green Governance" and "ICT Green Alignment". Taking into account both internal and external perspectives, has also been described in the model to better understand the constraints and objectives of different stakeholders in the ICT management process.

The enhanced eco-strategy model represents a structural and holistic research approach that leads us to the need to look at horizontal and transversal management modes that meet the expectations of all social, economic and environmental partners. This innovative approach to ICT management is based on a simple principle aimed at implementing the basic 
concepts of SD. In order to approve the validity and applicability of the proposed model, the conceptual Framework of the eco-strategy should be tested on the basis of a real case study.

The research we have conducted can be seen as a first step towards a more thorough and rigorous approach to conducting reflection on ICT management systems according to the SD concept. That is why we consider it more appropriate to start from this model as a basis, in order to build a new generation management repository that will be based on the principles of Green IT and CSR.

\section{REFERENCES}

[1] Hba R, Bakkas A, El Manouar A, Janati Idrissi M A, «Eco-strategy: Towards a new generation managerial model based on Green IT and CSR», International Journal of Computer Science \& Information Technology (IJCSIT) Vol 8, No 2 , April 2016

[2] Elkington, J. (1997) Cannibals with Forks: The Triple Bottom Line of 21st Century Business. Capstone, Oxford

[3] Hallstedt S., Ny H., Robèrt KH, Broman G., «An approach to assessing sustainability integration in strategic decision systems for product development», Journal of Cleaner Production, Volume 18, Issue 8, 2010

[4] Reyes T., Millet D. and Joan M., "Development of eco-design integration trajectories: two surveys and LCA case of study with a power distribution product" International Conference on engineering Design ICED'07, 28-31 August 2007, Paris.

[5] Pardo R. J H., Brissaud D., Zwolinski P, «Contribution to the characterization of eco-design projects», International journal of sustainable engineering, Volume 4, Issue 4, 2011, pages 301-312

[6] Melville, N. (2010) «Information Systems Innovation for Environmental Sustainability,» MISQuarterly 34, pp. 1-21

[7] Elliot, S. (2010) «Transdisciplinary Perspectives on Environmental Sustainability: A Resource Base and Framework for IT Enabled Business Transformation», MISQuarterly 35, pp.1-1

[8] Ansoff, I., Corporate strategy, McGraw Hill, New York, 1965

[9] Anthony, R.N., and Dearden, J. (1965). Management Control Systems, Irwin, Homewood, IIl.

[10] Gartner Business Intelligence \& Information Management Summit 2014, 24 25 February | Hilton Hotel, Sydney, Australia

[11] GartnerAnnual Report, 2014

[12] Ward, J. \& Daniel, E. (2006). Benefits Management, Delivering Value from IS and ITInvestments. John Wiley \& Sons, Chichester, UK

[13] Ward, J \&Peppard, J. (2003) Strategic Planning for Information Systems, Third Edition, John Wiley \& Sons, Chishester, UK

[14] C. W. L. Hill and F. T. Rothaermel, «The Performance of Incumbent Firms in the Face of Radical Technological Innovation,» Academy of Management Review 28 (2003): 257-274.

[15] ANSOFF H and STEWART JM (1967) Strategies for a technology-based business. Harv. Bus. Rev. 45 (6), 71-83

[16] Abernathy, William J., and Utterback, James M. (1978). Patterns of Industrial Innovation. Technology Review, 80(7), 40-47.

[17] Burgelman, Robert A., Modesto A. Maidique and Steven C. Wheelwright 1996. Strategic Management of Technology and Innovation, Irwin, Chicago.

[18] Betz, Frederick 1998. Managing Technological Innovation, John Wiley, McGraw-Hill, New York.

[19] Betz, Frederick 1994. Strategic Technology Management, McGraw-Hill, New York.

[20] Rennings, K. (2000), Redefining Innovation - Eco-Innovation Research and the Contribution from Ecological Economics, Ecological Economics, Vol. 32,

\section{9-332.}

[21] Jenkin, T.A., Webster, J. \& McShane, L., 2011. An agenda for «Green» information technology and systems research.Information and Organization, 21(1).

[22] Siegel, Donald S.. «Green Management Matters Only If It Yields More Green: An Economic/strategic Perspective».Academy of Management Perspectives 23.3 (2009): 5-16.

[23] Scott, Murray and Watson, Robert, "The Value of Green IT: a Theoretical Framework and Exploratory Assessment of Cloud Computing" (2012). BLED 2012 Proceedings. Paper 30.

[24] Watson, R.T., Boudreau, M.C., and Chen, A.J. (2010) Information Systems and Environmentally SustainableDevelopment: Energy Informatics and New Directions for the IS Community, MIS Quarterly, 34, 1, 22-38.

[25] Galbreath, J. (2006) Does primary stakeholder management positively affect the bottom line?: Some evidence from Australia. Management Decision 44: 1106-1121.

[26] Jo, H. \&Harjoto, M.A. (2011) «Corporate governance and firm value: The impact of corporate social responsibility». Journal of Business Ethics 103: 351383.

[27] Lyon, T. P. \& Maxwell, J.W. (2008) «Corporate social responsibility and the environment: A theoretical perspective. Review of Environmental Economics and Policy» 1: 1-22.

[28] Faucheux, S., Nicolai, I., 1998. Environmental technological change and governance in sustainable development policy. Ecol. Econom. 27 (1998), 243256.

[29] Porter, M.E., van der Linde C., 1995b. Green and Competitive.Ending the Stalemate. Harvard Business Review, September-October 1995, pp. 120-134.

[30] Rennings, K., Wiggering, H., 1997. Steps towards indicators of sustainable development - linking economic and ecological concepts. Ecol. Econom. 20, 25-36.

[31] Acemoglu, D., Aghion, P., Bursztyn, L., Hemous, D., 2012. The Environment and Directed Technical Change. American Economic Review, n¹02, p.131166.

[32] Andersen, M.M., 2010. Eco-innovation Dynamics - Creative Destruction and Creative accumulation in green Economic Evolution, in: Innovation, Organization, Sustainability and Crises. Presented at the Schumpeter Conference 2010, Aalborg June 21-24, 2010, Aalborg, Denmark, 26 p.

[33] Diemer, A., 2012. La technologie au coeur du DD : mythe ou réalité ? Innovations, 37, 73-94.

[34] Congrès européen «Eco-technologies pour le futur », 2011, Lille, 7 juin.

[35] Joller, L., 2012. Eco-innovation in business models-theoretical considerations. DRUID Academy Conference, University of Cambridge, UK, 1-10.

[36] Lubin, D.A., Esty, D.C. (2010). The Sustainability Imperative - Lessons for Leaders from Previous Game-Changing Megatrends, Harvard Business Review, 88, 5, 42-50.

[37] Teece, D. J., Pisano, G. and Shuen, A. (1997), Dynamic capabilities and strategic management. Strat. Mgmt. J., 18:509-533. doi:10.1002/(SICI)10970266(199708)18:7<509::AID-SMJ882>3.0.CO;2-Z

[38] Hart, S.L., Milstein, M.B. (2003). Creating Sustainable Value, Academy of Management Executive, 17, 2, 56-67

[39] Bieker, T. (2005). Sustainability Management with the Balanced Scorecard, Institute for Economy and the Environmentat the University of St. Gallen, St. Gallen.Haut du formulaire

[40] Harmon, R.R., Auseklis, N. (2009) Sustainable IT Services - Assessing the Impact of Green Computing Practices, Proceedings of the Portland International Center for Management of Engineering and Technology (PICMET), Portland, Oregon.

[41] Luftman, J. (2004) Key Issues for IT Executives 2004, MIS Quarterly Executive, 4, 2, 269-286.

[42] Ravichandran, T., Lertwongsatien, C. (2005) Effect of Information Systems 
Resources and Capabilities on FirmPerformance - A Resource-Based Perspective, Journal of Management Information Systems, 21, 4, 237-276.

[43] Henderson, C., and Venkatraman, N. (1993) Strategic Alignment - Leveraging Information Technology for Transforming Organizations, IBM Systems Journal, 32, 1, 472-484.

[44] Wang, H.-L., Ghose, A. (2006). On the foundations of strategic alignment. The Proceedings of the 2006 Australia and New Zealand Academy of Management Conference. Dunedin, New Zealand, December 2006.

[45] Wang, H.-L., Ghose, A. (2011). Green strategic alignment: Aligning business strategies with sustainability objectives. In B. Unhelkar, ed., Handbook of Research in Green ICT: Technical, Business and Social Perspectives, pp. 29-41. IGI Global, Hershey, PA, USA.

[46] Chan, Y.E., Reich, H.B., IT alignment: what have we learned?, Journal of Information Technology, 00, pp. 1-19, 2007.

[47] Kaplan, R. S. and D.P. Norton (1992) The Balanced Scorecard: Measures that Drive Performance, Harvard Business Review, (January-February): 71-79.
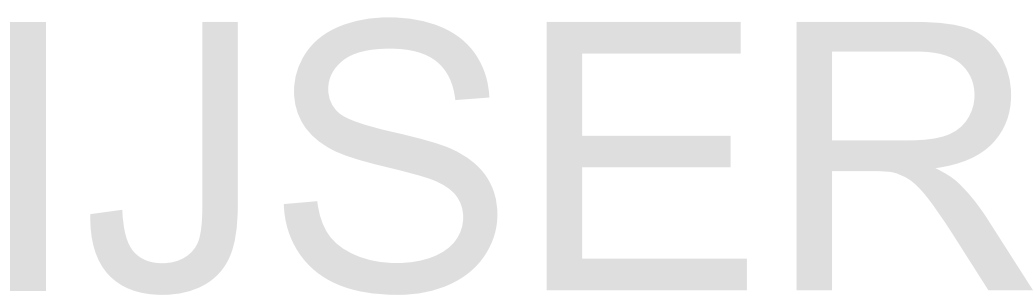